\title{
Analisis Pengaruh Kompetensi Guru Terhadap Keberhasilan Pembelajaran Di Sekolah Dasar Bethel Tanjung Priok Jakarta Utara
}

\author{
Jannes Eduard Sirait \\ Sekolah Tinggi Teologi Bethel Indonesia \\ janneseduardsirait@yahoo.co.id
}

\begin{abstract}
Abstrak
Masalah tentang guru sebagai pendidik merupakan topik riset yang tidak habis untuk diteliti. Peran penting guru masih tetap diyakini sebagai salah satu faktor paling utama dalam menentukan keberhasilan pembelajaran. Sebagai pendidik, guru harus memiliki komptensi yang baik sehingga dapat menjadi pendidik yang kreatif dan produktif serta mampu melakukan inovasi-inovasi dalam pembelajaran. Kompetensi guru mencakup bidang kognitif, sikap dan perilaku atau performance. Tujuan penelitian ini adalah untuk mengetahui pengaruh kompetensi guru terhadap keberhasilan pembelajaran di Sekolah Dasar Bethel Tanjung Priok. Metode yang digunakan adalah survey dengan pendekatan kuantitatif. Populasi penelitian sebanyak 20 orang dan sampel adalah 19 orang guru SD Bethel Tanjung Priok, dan diambil dengan teknik Random. Menentukan jumlah sampel menggunakan formula emperis yang dianjurkan oleh Isaac \& Michael. Tetapi karena populasi kurang dari 100 orang maka semua populasi dijadikan sebagai responden sehingga penelitian ini dilakukan secara sensus. Analisa data penelitian menggunakan metode statistika dengan bantuan program SPSS. Prosedur pengolahan data dilakukan dengan cara (1) menyeleksi data; (2) menentukan bobot nilai jawaban item penelitian dan skor; (3) melakukan analisa deskriptif; dan (4) uji regresi. Dari hasil penelitian dapat disimpulkan bahwa kompetensi guru berpengaruh signifikan terhadap keberhasilan pembelajaran di SD Bethel Tanjung Priok Jakarta Utara.
\end{abstract}

Kata kunci: pengaruh, kompetensi guru, keberhasilan pembelajaran. 


\section{PENDAHULUAN}

Pembelajaran merupakan proses terjadinya interaksi antara guru dan siswa melalui kegiatan terpadu dari dua bentuk kegiatan, yakni kegiatan belajar dan kegiatan mengajar. Interaksi pembelajaran bergantung pada jenis komunikasi yang digunakan, apakah komunikasi sebagai aksi, interaksi, dan sebagai transaksi. Guru adalah salah satu faktor penentu keberhasilan pembelajaran. Maka, guru perlu memiliki kompetensi sebagai pendidik. Menyatakan bahwa guru diminta kemampuannya untuk menunjukkan kompetensinya dalam meraih keberhasilan pembelajaran. Mampu menyusun kegiatan mulai dari tahapan belajar hingga evaluasinya dan mampu menciptakan atmosfir belajar yang kondusif.

Kompetensi guru dan keberhasilan pembelajaran adalah dua hal utama dalam pelaksanaan kegiatan belajar mengajar. Sehingga pendidik yang tidak memiliki kemampuan optimal akan menjadi sebuah keperihatinan dan perlu disikapi, karena memberi dampak buruk terhadap keberhasilan pembelajaran. Itu sebabnya, masalah kompetensi guru menjadi isu serius. Pernyataan tersebut bermakna, bahwa esensi dari kompetensi guru yang baik adalah terciptanya keberhasilan pembelajaran.

\section{KAJIAN PUSTAKA}

Kompetensi adalah karakteristik dasar seorang guru yang menggunakan bagian kepribadiannya yang paling dalam dan dapat mempengaruhi perilakunya ketika menghadapi pekerjaan, yang akhirnya berpengaruh pada kemampuan untuk menghasilkan prestasi kerja. Menurut Bambang Sumardjoko (2010:77), kompetensi ini terbentuk atas lima karakteristik, yaitu: watak, motif, konsep diri, pengetahuan, dan keterampilan.

Kompetensi merupakan penampilan rasional untuk mencapai tujuan-tujuan yang diinginkan dengan menyenangkan. Maka, kompetensi dapat disebut penampilan spesifik yang rasional sebagai harmoni dan pemilihan pengetahuan, keterampilan , dan kemampuan yang dibutuhkan oleh tugas pekerjaan untuk mencapai tujuan-tujuan yang telah ditetapkan dengan keberhasilan. 
DIEGESIS: Jurnal Teologi

Volume 6 No. 1, Februari 2021 Hlm 49-69

Menjadi guru adalah tugas profesional. Soetjipto dan Raflis Kosasi (2009:37) berujar: "sebagai jabatan profesional, pemegangnya harus memenuhi kualifikasi tertentu." Profesional berasal dari kata profesi (profession) yang diartikan sebagai jenis pekerjaan khas yang mana memerlukan pengetahuan, keahlian atau ilmu pengetahuan yang digunakan dalam aplikasi untuk berhubungan dengan orang lain, instansi atau lembaga. Selanjutnya Nurdin (2005:13), mengatakan profesional adalah (1) bersangkutan dengan profesi, (2) memerlukan kepandaian khusus untuk menjalankannya dan (3) mengharuskan adanya pembayaran untuk melakukannya."

Guru sebagai pendidik profesional diharuskan untuk memiliki kemampuan khusus, penampilan atau unjuk kerja dan kemampuan strategis termasuk kemampuan taktis dan teknis. Kemampuan-kemampuan tersebut akan memberi pengaruh terhadap kinerjanya. Menunjukkan bahwa kompetensi guru selalu berhubungan dengan kreativitas yang ditampilkan. Martinis Yamin dan Maisah (2010:28) menegaskan bahwa, "berkompeten adalah yang mengedepankan mutu dan kualitas layanan dan produknya, layanan guru harus memenuhi standarisasi kebutuhan masyarakat, bangsa dan pengguna serta memaksimalkan kemampuan peserta didik berdasarkan potensi dan kecakapan yang dimiliki masing-masing individu."

Ada enam unsur kompetensi yang harus dimiliki oleh pendidik, yakni: (1) komponen kreativitas yang merupakan totalitas perilaku yang ditampilkan dari pengetahuan, keterampilan, proses dan nilai untuk membuat keputusan bagi penampilan pribadi dalam mencapai tujuan pembelajaran; (2) Komponen bahan pengajaran yang merupakan kumpulan ilmu pengetahuan yang digabungkan dengan tujuan pembelajaran. (3) Komponen proses pengajaran; (4) Komponen penyesuaian pribadi; (5) Komponen profesional pengajaran; dan (6) Komponen sikap (Sumardjoko, 2010:81-82).

Seorang guru perlu memiliki keberanian berinovasi dalam pembelajaran guna mengembangkan pembelajaran bermutu, dinamis dan bermakna. Kompetensi selalu 
berhubungan erat dengan profil guru, walaupun potret guru yang ideal memang sulit di dapat namun kita boleh menebak profilnya. Pendidik berkompeten merupakan produk dari keseimbangan antara penguasaan aspek keguruan dan disiplin ilmu. Keduanya pun tidak perlu dipertentangkan melainkan bagaimana guru tertempah kepribadiannya dan terasah aspek penguasaan materinya. Untuk mencapai maksud tersebut, maka seorang guru harus memastikan bahwa dirinya adalah bermutu dan senantiasa memeliharanya. Berdasarkan uraian ini, maka kompetensi merupakan karakter sikap, perilaku, kemauan serta kemampuan yang relatif stabil ketika menghadapi situasi atau kondisi di tempat kerjanya, yang terbentuk dari kombinasi antara watak, konsep diri, motif, pengetahuan, dan keterampilan.

Kompetensi guru pada dasarnya menunjuk kepada kecakapan atau kemampuan untuk mengerjakan suatu pekerjaan. Pada dasarnya kompetensi merupakan sifat (karakteristik) dari orang-orang berkompeten adalah memiliki kecakapan, daya (kemampuan), otoritas (kewenangan), kemahiran (keterampilan), dan pengetahuan. Wina Sanjaya (2006:17-18) mengutif pendapat Charles E. Johnson menyebutkan: "kompetensi sebagai perilaku rasional guna mencapai tujuan yang dipersyaratkan sesuai dengan kondisi yang diharapkan."

Husdarta

(2009:111)

menjelaskan, kompetensi sebagai suatu penampilan yang rasional yang dapat mencapai tujuan-tujuan yang diinginkan dengan penuh kesenangan. Kompetensi akan terlihat dari penampilan atau unjuk kerja dan yang dapat rasional dalam upaya mencapai suatu tujuan. Sanjaya (2006:19) mengatakan, "bahwa sebagai suatu profesi maka kompetensi seorang guru meliputi kompetensi pribadi, kompetensi profesional, dan kompetensi sosial kemasyarakatan.” Kompetensi adalah suatu pemilikan pengetahuan, keterampilan, dan kemampuan yang dituntut oleh pekerjaan. Kompetensi dapat pula dimaknai sebagai kapasitas yang dimiliki seseorang untuk bekerja. Dalam UndangUndang Guru dan Dosen No. 14/2005 Pasal 10 dan Peraturan Pemerintah 
DIEGESIS: Jurnal Teologi

Volume 6 No. 1, Februari 2021 Hlm 49-69

No. 19/2005 disebutkan bahwa kompetensi guru meliputi kepribadian, paedagogik, profesional, dan sosial.

Komptensi guru merupakan karakter sikap, perilaku atau kemauan, serta kemampuan yang relatif stabil ketika menghadapi situasi atau kondisi di tempat kerjanya, yang terbentuk dari kombinasi watak, konsep diri, motif, pengetahuan, dan keterampilan. Kompetensi pada dasarnya menunjukkan kecakapan atau kemampuan untuk mengerjakan suatu pekerjaan dan merupakan suatu sifat orang-orang yang berkompeten, yang memiliki kecakapan, kemampuan, kewenangan, keterampilan, dan pengetahuan. Indikator kompetensi guru dalam hal ini mencakup kompetensi sebagaimana dalam Undang-Undang Pendidik dan Guru yang meliputi kompetensi pedagogik, kepribadian, profesional, dan kompetensi sosial.

Pendidik yang berkompeten akan dapat melaksanakan tugasnya secara profesional. Itu alasannya, mengapa dibutuhkan pemeliharaan dan peningkatan kompetensi. Pemeliharaan dan peningkatan kompetensi tersebut merupakan tuntutan yang urgen. Upaya tersebut dengan sendirinya akan memberi pengakuan bahwa setiap individu guru haruslah bekerja secara profesional sesuai dengan kompetensi atau kepakaran yang dimilikinya. Berikut ini dijumpai beberapa upaya yang dapat dilakukan dalam peningkatan kompetensi guru, yaitu: 1) Peningkatan kompetensi melalui pendidikan yang tersedia; 2) Pendidikan profesional lanjutan di lembaga pelayanan; 3) Pendidikan profesi lanjutan oleh penyedia lain; 4) Peningkatan melalui personal learning project; dan 5) Peningkatan melalui group learning project. Semua hal ini akan menjadikan pendidik mampu meningkatkan kompetensinya sebagai pendidik guna menunjang keberhasilan proses pembelajaran.

Keberhasilan pembelajaran menjadi tujuan utama dari kegiatan pendidikan di sekolah. Frasa keberhasilan (hasil) artinya pendapatan, perolehan, buah. Berhasil berarti mendapat hasil, tidak gagal. Mengeluarkan hasil, ada hasilnya, tercapai maksudnya, tidak gagal (W.J.S. Puwardarminta, 1978:348-349). Maka, keberhasilan pembelajaran dapat diartikan dengan 
tercapainya, mendapat hasil dan tidak gagal serta tercapai maksud dari proses kegiatan belajar mengajar. Atau tercapainya tujuan pembelajaran yang ditetapkan sebelumnya. Untuk mengetahui ketercapaian tujuan pembelajaran perlu dilakukan evaluasi. Penilaian ini dimaksukan untuk mengetahui sejauh mana pembelajaran telah mencapai tujuan instruksional khusus (TIK). Penilaian ini juga berfungsi untuk memberikan umpan balik kepada guru dalam memperbaiki proses kegiatan pembelajaran.

Pembelajaran merupakan suatu sistem yang kompleks. Keberhasilan pembelajaran juga dapat dilihat dari aspek hasil dan aspek proses. Keberhasilan pembelajaran adalah aspek produk proses kegiatan pembelajaran. Aspek tersebut berbicara mengenai hasil yang diperoleh melalui proses pembelajaran tersebut. Hasil belajar yang dicapai tidak boleh menyimpang dari tujuan pembelajaran yang direncanakan. Dalam proses perencanaan dan desain pembelajaran, harus tetap menjadikan peserta didik sebagai pusat dari kegiatan pembelajaran. Artinya, keputusan-keputusan yang diambil dalam perencanaan dan desain pembelajaran senantiasa disesuaikan dengan kondisi totalitas peserta didik mulai dari kemampuan dasar, minat dan bakat, motivasi belajar, dan gaya belajar siswa. Untuk mencapai keberhasilan pembelajaran, maka guru bertindak sebagai fasilitator handal membawa peserta didik agar dapat belajar sesuai minat, motivasi, dan gayanya sendiri. Mendesain pembelajaran dengan baik akan memungkinkan mereka memperoleh pengalaman belajar yang baik. Maka, guru harus dapat menggambarkan apa yang harus dilakukan dan mampu memanfaatkan sumber belajar secara optimal.

Hasil belajar adalah kemampuan yang diperoleh anak setelah melalui kegiatan belajar. Asep Jihad dan Abdul Haris (2008:14) mengatakan, "dalam kegiatan pembelajaran atau kegiatan instruksional, biasanya menetapkan tujuan belajar.

Pembelajaran dikatakan behasil adalah ketika berhasil mencapai tujuan yang ditetapkan.” Kriteria keberhasilan pengajaran dan untuk menjawab pernyataan ini harus 
DIEGESIS: Jurnal Teologi

Volume 6 No. 1, Februari 2021 Hlm 49-69

terlebih dahulu menentukan apa yang menjadi kriteria dari keberhasilan pengajaran. Kriteria ini dimaksudkan menjadi ukuran ataupun patokan dalam menentukan tingkat keberhasilan.

Melalui kriteria tersebut, maka pengajaran dapat diukur. Apakah sudah mencapai kriteria atau masih jauh, bahkan menyimpang dari kriteria. Menurut Sudjana (1998:35), kriteria keberhasilan pembelajaran ini dapat dilihat dari dua kriteria umum, yakni (a) kriteria dari sudut prosesnya (by process) dan (b) kriteria dari sudut hasil yang dicapainya (by product).

Kriteria dari sudut proses menekankan kepada pengajaran sebagai suatu proses harus menjadi interaksi dinamis sehingga siswa sebagai subyek belajar mampu mengembangkan potensinya melalui belajar sendiri, dan dapat tujuan yang telah ditetapkan secara efektif. Kriteria keberhasilan dari segi hasil menekankan tingkat penguasaan tujuan oleh peserta didik baik dari segi kualitas maupun kuantitas. Sudjana (1998:35), menegaskan, "bahwa kedua kriteria tersebut tidak dapat berdiri sendiri tetapi harus merupakan hubungan sebab akibat. Dengan kriteria tersebut berarti pengajaran bukan hanya mengejar hasil yang setinggi-tingginya dan mengabaikan proses tetapi keduanya ada dalam keseimbangan." Dengan kata lain pengajaran tidak sematamata output oriented tetapi njuga proses oriented.

Pembelajaran pada hakikatnya harus terjadi secara dinamis, penuh kreasi dan inovatif serta mengembangkannya ke arah yang lebih baik.

Kegiatan belajar harus didesain menjadi kebutuhan pokok bagi peserta didik dan tidak sekedar memenuhi kehadiran di dalam kelas. Keberhasilan pembelajaran tersebut akan tercermin dari minat, niat dan tekad belajar yang dimilikinya. Proses pembelajaran yang baik akan memberi kesempatan pada peserta didik mengikuti proses kegiatan belajar mengajar menurut kapasitasnya.

Biasanya disiplin sangat mempengaruhi keberhasilan belajar siswa. Itu sebabnya, guru harus bijaksana dan mampu mengelola kelas guna terciptanya iklim belajar yang baik, sehingga peserta didik merasa aman, sukacita, tenang dan menyenangkan. Selain itu, perlu memperhatikan sarana dan prasarana 
yang digunakan. Apabila semuanya tidak terpenuhi maka pada akhirnya pembelajaran akan menjenuhkan dan suasana seperti ini dapat menghambat keberhasilan pembelajaran.

Menyimak item-item persoalan yang disajikan maka keberhasilan pembelajaran dipengaruhi oleh banyak variabel yang sumbernya dari pribadi peserta didik, usaha guru dalam mengatur kondisi pembelajaran dan variabel lingkungan terutama sarana dan iklim yang baik. Keterpaduan semua variabel tersebut adalah kunci dalam mencapai keberhasilan pembelajaran jika ditinjau dari sudut proses.

Keberhasilan pembelajaran dapat dilihat dari segi hasil. Asumsi dasar ialah proses pengajaran yang optimal memungkinkan hasil belajar yang optimal pula. Ada korelasi antara proses pengajaran dengan hasil yang dicapai. Makin besar usaha untuk menciptakan kondisi proses pengajaran, makin tinggi pula hasil atau produk dari pengajaran itu. Perubahan yang ditemukan dalam diri peserta didik sebagai hasil belajar mudah diukur, yaitu: dapat dilihat dan diamati, bersifat khusus dan operasional. Keberhasilan pembelajaran dari sudut hasil yang diperoleh peserta didik akan membentuk sistem nilai yang dapat membentuk kepribadian siswa, sehingga memberi warna dan arah dalam tindakannya. Karena itu, pendidik memikul tanggung jawab atas keberhasilan dan kegagalan pembelajaran. Sebab itu mengajar adalah pekerjaan profesional, bukan pekerjaan sambilan atau pekerjaan tambahan. Mencintai profesi merupakan prasyarat bagi guru dan dari sinilah awal keberhasilan pembelajaran.

Indikator yang banyak dipakai sebagai indikator atau tolok ukur keberhasilan pembelajaran adalah daya serap. Keberhasilan itu dilihat dari segi keberhasilan proses dan keberhasilan produk. Namum untuk menyamakan persepsi harus berpedoman kepada kurikulum yang berlaku. Suatu proses belajar mengajar tentang suatu bahan pengajaran dinyatakan berhasil apabila tujuan instruksional khusus dapat tercapai (Djamarah dan Zain, 2006:119). Petunjuk bahwa suatu proses belajar mengajar dianggap berhasil dapat dilihat dari ukuran (1) daya serap terhadap bahan pengajaran 
yang diajarkan mencapai prestasi tinggi, baik secara individual maupun kelompok. (2) Perilaku yang digariskan dalam tujuan pengajaran telah dicapai oleh siswa baik secara individual maupun kelompok (tercapai (Djamarah dan Zain, 2006:120).

Menilai keberhasilan

pembeajaran juga dapat dilakukan melalui evaluasi sekaligus menetapkan tingkat atau tarap keberhasilan pembelajaran dalam suatu periode tertentu. Dalam praktek penilaian, maka hasil evaluasi akan memberi gambaran tentang keberhasilan proses kegiatan belajar mengajar. Informasi yang diberikan melalui hasil analisis sangat diperlukan bagi pembuatan kebijakan-kebijakan yang harus dilakukan guna peningkatan proses pembelajaran berikutnya. Mengukur tingkat keberhasilan tersebut juga dapat diperoleh melalui evaluasi prestasi belajar peserta didik.

Tingkat keberhasilan tersebut menjadi patokan ketercapaian penyerapan para peserta didik terhadap pembelajaran. Walaupun tingkat penguasaan dan daya serap setiap peserta didik berbeda-beda. Namun melalui data yang diperoleh dapat diketahui tarap keberhasilan kegiatan belajar mengajar yang dilakukan siswa dan guru. Keberhasilan proses belajar mengajar dibagi atas beberapa tingkatan, yaitu: (1) Taraf istimewa/maksimal: apabila seluruh bahan pelajaran yang diajarkan itu dapat dikuasai oleh siswa. (2) Taraf baik sekali/optimal: apabila sebagian besar $(76 \%$ s.d. 99\%) bahan pelajaran yang diajarkan dapat dikuasai oleh siswa. (3) Taraf baik/maksimal: apabila bahan pelajaran yang diajarkan hanya $60 \%$ s.d. $75 \%$ saja dikuasai oleh siswa. (4) Kurang: apabila bahan pelajaran yang diajarkan kurang dari $60 \%$ dikuasai oleh siswa (Djamarah dan Zain, 2006:121-122).

Jihad dan Haris (2008:61) mengatakan, "Guru dapat memanfaatkan hasil penilaian untuk perbaikan program dan kegiatan pembelajaran. Perbaikan program tidak perlu menunggu sampai akhir semester, karena bila dilakukan pada akhir semester bisa saja perbaikan itu akan sangat terlambat." Oleh karena itu, program yang telah dirancang, strategi pembelajaran yang telah disiapkan, dan bahan yang telah disiapkan perlu dievaluasi, direvisi, atau mungkin diganti apabila ternyata 
tidak efektif membantu peserta didik dalam mencapai penguasaan kompetensi.

Djamarah dan Zain (2006:123) mengatakan, "umumnya pengajaran perbaikan biasanya mengandung kegiatan-kegiatan (1) mengulang pokok bahasan seluruhnya, (2) mengulang bagian dari pokok bahasan yang hendak dikuasai, (3) memecahkan masalah atau menyelesaikan soal-soal bersamasama, (4) memberikan tugas-tugas khusus." Taraf atau tingkat keberhasilan proses belajar mengajar dapat dimanfaatkan untuk berbagai upaya. Salah satunya adalah berkaitan dengan kelangsungan proses belajar mengajar itu sendiri. Karena itu, pengukuran harus betul-betul syahih (valid), handal (reliabel), dan lugas (objective).

Umumnya keberhasilan pembelajaran yang dilakukan dipengaruhi oleh dua faktor, yakni faktor dari peserta didik dan faktor dari luar dirinya. Faktor peserta didik terutama kemampuan yang dimilikinya. Faktor kemampuan peserta didik memiliki pengaruh yang sangat besar terhadap hasil pembelajaran yang dicapai
(Sudjana:1998:39). Disamping faktor tersebut, juga terdapat ada faktor lain, seperti motivasi belajar, minat dan perhatian, sikap dan kebiasaan belajar, ketekunan, sosial ekonomi, faktor fisik dan psikis.

Salah satu faktor yang turut mempengaruhi keberhasilan dan kualitas pengajaran adalah variabel guru. Karena pendidik adalah sutradara dan aktor dalam proses pembelajaran tanpa mengesampingkan hal-hal lain seperti buku pelajaran, alat bantu pengajaran dan lain-lain. Dari variabel guru yang paling dominan mempengaruhi keberhasilan pembelajaran adalah kompetensi yang dimilikinya. Kopetensi guru, baik pada bidang kognitif (intelektual), seperti penguasaan bahan, bidang sikap seperti mencintai profesinya dan bidang perilaku seperti keterampilan mengajar, menilai hasil belajar siswa dan lain-lain.

Menurut Sudjana (1998:42), “di samping faktor guru, kualitas pengajaran dipengaruhi juga oleh karakteristik kelas. Variabel karakteristik kelas antara lain: (a) besarnya kelas; (b) suasana kelas; (c) fasilitas dan sumber belajar yang 
DIEGESIS: Jurnal Teologi

Volume 6 No. 1, Februari 2021 Hlm 49-69

tersedia." Faktor lain yang melakukan penyusunan dan mempengaruhi kualitas dan perencanaan pembelajaran dengan keberhasilan pengajaran di sekolah baik, memiliki kemampuan adalah karakteristik sekolah itu sendiri. Karakteristik sekolah berkomunikasi yang efektif, berkaitan dengan disiplin sekolah, mengembangkan efektivitas perpustkaan yang ada disekolah, letak geografis sekolah, lingkungan sekolah, estetika dalam arti sekolah memberikan perasaan nyaman, dan kepuasan belajar, bersih, rapih dan teratur.

Dengan demikian dapat diringkaskan bahwa ada tiga unsur utama dalam keberhasilan pembelajaran yang berpengaruh terhadap hasil belajar siswa, yakni kompetensi guru, karakteristik kelas dan karakteristik sekolah. Djamarah dan Zain (2006:121-123), mengatakan bahwa: "faktor yang mempengaruhi keberhasilan kegiatan pembelajaran dapat dilihat dari beberapa komponen pembelajaran mulai dari tujuan pembelajaran, guru sebagai pendidik, anak didik, kengiatan pengajaran, bahan dan alat evaluasi dan suasana evaluasi."

Upaya yang dapat dilakukan untuk meningkatkan efektivitas pembelajaran, yaitu, perencanaan, komunikasi, pengajaran, pengaturan pembelajaran, memiliki kemampuan menguasai dan mencptakan iklim kelas yang baik, dan melakukan evaluasi secara benar dan tepat.

Berkaitan dengan isu sentral tersebut, peneliti mencoba mengidentifikasi berbagai hal yang berkaitan dengan pokok persoalan, secara khusus faktor-faktor yang mempengaruhi kompetensi guru yang berdampak terhadap keberhasilan pembelajaran dan menjadikannya sebagai variabel kajian.

Kajian realitas dilapangan melalui observasi awal memunculkan berbagai variabel berpengaruh terhadap keberhasilan pembelajaran. Namun penelitian ini difokuskan untuk menemukan pengaruh kompetensi guru berdampak pengaruh terhadap keberhasilan pembelajaran yang lokasi penelitiannya di Sekolah Dasar Bethel Tanjung Priok Jakarta Utara guna memberi kontribusi yang relevan dengan variabel yang akan diteliti.

dan evaluasi. Karena itu, guru perlu 


\section{METODE PENELITIAN}

Metode yang digunakan dalam penelitian ini adalah survey penjelasan (explanatory survey method) dengan pendekatan kuantitatif. Prosedur penelitian mengikuti langkah-langkah umum penelitian. Populasi dalam penelitian ini adalah guru Sekolah Dasar Bethel Tanjung Priok yang melakukan kegiatan pembelajaran 2019/2020 sebanyak 20 orang.

Pengambilan sampel adalah Random dengan simple random sampling dan penentuan jumlah sampel menggunakan formula emperis yang dianjurkan oleh Isaac \& Michael. Menurut tabel tersebut, jika $\mathrm{N}=20$ maka $\mathrm{S}=19$ orang (Ridwan dan Engkos, 2007:51). Tetapi karena populasi kurang dari 100 orang maka semua populasi dijadikan responden sehingga penelitian ini dilakukan secara sensus dan semakin besar jumlah sampel maka akan semakin representatif.

Pengumpulan data menggunakan angket yang diawali dengan penyusunan indikatorindikator berdasarkan variabel penelitian. Selanjutnya indikator dikembangkan menjadi item-item pertanyaan yang dilengkapi dengan 5 alternatif jawaban berdasarkan skala sikap metode likert. Angket terdiri dari 2 bagian sesuai dengan jumlah variabel. Tiap-tiap variabel terdiri dari beberapa dimensi dan indikator sebagai acuan dalam mengembangkan instrumen.

Uji validitas instrumen variabel independen pada signifikasi 0,05 dengan uji 2 sisi dan jumlah data (n) $=20$, maka $\mathrm{r}$ tabel sebesar 0,444. Semua item berkorelasi signifikan. Variabel dependen, yaitu item nomor 2 dan nomor 13 memiliki nilai korelasi kurang dari 0,444, tidak berkorelasi signifikan dan harus dikeluarkan. Priyatno (2010:98) mengutip Sekaran (1992), reliabilitas kurang dari 0,6 adalah kurang baik, sedangkan 0,7 dapat diterima dan di atas 0,8 adalah baik. Pada output Reliability Statistics menunjukkan nilai Cronbach's Alpha variabel X adalah 0,939 dan Y sebesar 0,961 menunjukkan bahwa alat ukur penelitian adalah reliabel.

Analisa data penelitian menggunakan statistika dan penghitungannya menggunakan bantuan program SPSS 16. Prosedur pengolahan data dilakukan dengan 
cara (1) menyeleksi data; (2) menentukan bobot nilai setiap jawaban item penelitian, kemudian menentukan skor; (3) melakukan analisa deskriptif; dan (4) uji regresi.

\section{HASIL DAN PEMBAHASAN}

Data yang disajikan ini adalah jumlah hasil keseluruhan skor dari setiap variabel penelitian. Data hasil penelitian yang diperoleh tersebut, selanjutnya digunakan sebagai data dalam menganalisis pengaruh dari variabel dengan menggunakan teknik analisis data regresi. Semua pengolahan data penelitian akan diolah dengan bantuan program SPSS. Data penelitian yang diperoleh adalah setelah melakukan penelitian dilapangan. Kemudian dilakukan penjumlahan skor total jawaban responden dari semua variabel penelitian.

\section{One-Sample Kolmogorov-}

Smirnov Test memperlihatkan temuan uji normalitas variabel penelitian adalah test distribution is normal. Test for Linearity pada taraf signifikasi 0,05. Variabel penelitian mempunyai hubungan yang linear bila signifikasi (linearity) kurang dari 0,05 . Analisis data penelitian untuk mengetahui pengaruh variabel $\mathrm{X}$ terhadap $\mathrm{Y}$, maka pengujiannya dilakukan menggunakan analisis regresi sederhana.

\begin{tabular}{|c|c|c|c|c|c|}
\hline \multicolumn{6}{|c|}{ Coefficients $^{\mathrm{a}}$} \\
\hline \multirow[b]{2}{*}{ Model } & \multicolumn{2}{|c|}{$\begin{array}{c}\text { Unstandardiz } \\
\text { ed } \\
\text { Coefficients }\end{array}$} & \multirow{2}{*}{$\begin{array}{c}\begin{array}{c}\text { Standardiz } \\
\text { ed } \\
\text { Coefficien } \\
\text { ts }\end{array} \\
\text { Beta }\end{array}$} & \multirow[b]{2}{*}{$\mathrm{T}$} & \multirow[b]{2}{*}{ Sig } \\
\hline & B & $\begin{array}{c}\text { Std. } \\
\text { Error }\end{array}$ & & & \\
\hline 1 (Constant & $\begin{array}{c}65.51 \\
8\end{array}$ & $\begin{array}{c}22.26 \\
8\end{array}$ & & $\begin{array}{c}2.94 \\
2\end{array}$ & $\begin{array}{c}.00 \\
9\end{array}$ \\
\hline $\begin{array}{c}\text { Kompete } \\
\text { nsi Guru } \\
(\mathrm{X})\end{array}$ & .569 & .223 & .516 & $\begin{array}{c}2.55 \\
8\end{array}$ & $\begin{array}{c}.02 \\
0\end{array}$ \\
\hline \multicolumn{3}{|c|}{$\begin{array}{l}\text { a. Dependent Variable: } \\
\text { Keberhasilan } \\
\text { Pembelajaran (Y) }\end{array}$} & & & \\
\hline
\end{tabular}

Berdasarkan hasil perhitungan keseluruhan, maka hasil analisis memperlihatkan bahwa nilai Konstanta yang dimiliki adalah sebesar 65,518. Nilai ini menyatakan bahwa jika tidak ada kenaikan nilai dari variabel $\mathrm{X}$, maka nilai $\mathrm{Y}$ adalah tetap sebesar 65,518. Koefisien regresi yang dimiliki adalah 0,516 menyatakan bahwa setiap penambahan (karena tanda + ) satu skor maka $\mathrm{X}$ akan memberikan kenaikan skor sebesar 0,516. Uji t untuk menguji signifikasi konstanta dan variabel dependen $(\mathrm{Y})$. Nilai $\mathrm{t}(\mathrm{t}-$ hitung) dalam regresi menunjukkan pengaruh variabel independent secara parsial. Nilai probablitas t-hitung 
sebesar 0,020 menunjukkan hipotesis alternatif.

\begin{tabular}{|l|c|c|c|r|}
\hline \multicolumn{5}{|c|}{ Model Summary } \\
\hline $\begin{array}{l}\text { Mode } \\
1\end{array}$ & $\mathrm{R}$ & R Square & $\begin{array}{c}\text { Adjusted R } \\
\text { Square }\end{array}$ & $\begin{array}{c}\text { Std. Error of } \\
\text { the Estimate }\end{array}$ \\
\hline 1 & $.516^{\mathrm{a}}$ & .267 & .226 & 7.735 \\
\hline \multicolumn{5}{|c|}{ a. Predictors: (Constant), Kompetensi Guru (X) } \\
\hline
\end{tabular}

Untuk mengetahui signifikasi regresi sederhana bandingkan antara nilai probabilitas 0,05 . Terlihat bahwa kolom Sig (signifikan) pada Coefficients Variabel YX ternyata nilai probabilitas $\operatorname{sig}=0,020$ lebih kecil dari nilai probabilitas 0,05 atau nilai $0,05>0,020$, artinya koefisien regresi adalah signifikan. Besar nilai koefisien determinasi adalah sebesar 0,226 , berarti $22,6 \%$ variabel $\mathrm{Y}$ dapat dijelaskan oleh variabel X. Kemudian $77,4 \%$ variabilitas $\mathrm{Y}$ diterangkan oleh variabel lain. Simpulannya bahwa kompetensi guru berpengaruh signifikan terhadap keberhasilan pembelajaran.

Pembahasan penelitian ini didasarkan pada hasil analisis yang dikelola. Pokok- pembahasan penelitian ini didasarkan pada hipotesis penelitian yang diajukan, yaitu: "kompetensi guru berpengaruh terhadap keberhasilan pembelajaran." Hasil analisis menyatakan pengaruh signifikan.

Peneliti menginterpretasikannya bahwa guru yang memiliki kompetensi yang baik akan memberi dampak pengaruh positif terhadap keberhasilan pembelajaran di Sekolah Dasar Bethel Tanjung Priok.

Menekankan bahwa guru harus menjaga kompetensinya sebab berpengaruh bagi keberhasilan pembelajaran. Para ahli pendidikan umumnya menerima pandangan ini. Pendidik yang berkompeten akan mendorong keberhasilan pembelajaran dan memampukan pendidik melakukan banyak hal secara kreatif dan inovatif. Sebaliknya, jika tidak berkompeten maka dengan sendirinya akan berhenti melakukan pekerjaan terbaik sebab kompetensi guru sangat identik dengan keberhasilan.

Keberhasilan tersebut akan memberi kepuasan dan mendorong setiap orang melakukan pekerjaanya dengan penuh motivasi. Sebab sekalipun seseorang sangat terampil dalam melakukan pekerjaan namun apabila tidak memberi kepuasan atau keuntungan maka hal itu akan menghambat keberhasilan. Sekalipun demikian, guru sebagai pendidik profesional tetap bertanggung jawab 
untuk menjaga, memelihara dan meningkatkan kompetensinya.

Minimal mempertahankan

kompetensi yang sudah dan sedang dimiliki sekarang. Guru harus serius dalam meningkatkan kompetensi pedagogik, kepribadian, profesional dan kompeensi sosial pendidik.

Keberhasilan pembelajaran juga dipengaruhi faktor lingkungan tempat bekerja. faktor-faktor yang mempengarui lingkungan sekolah mencakup: kebersihan, penerangan, ventilasi udara, penerangan lampu, perabot, alat perlengkapan, situasi dan kondisi lingkungan sekolah, tata ruang (lay out), keamanan. Menurut Riduan dan Kuncoro (2009:237) selain memperhatikan faktor-faktor tersebut, harus memenuhi insentif yang jelas untuk memotivasi dan memberi hadiah kepada pendidik yang berprestasi. Hal ini akan membantu memotivasi mereka untuk meningkatkan kompetensinya.

Menurut UUGD, pendidik wajib memiliki kompetensi dengan kualifikasi akademik yang baik. Selain itu, pendidik berkompeten juga diwajibkan memiliki berbagai kemampuan khusus. Memiliki penampilan atau unjuk kerja, kemampuan strategis dan kemampuan taktis serta kemampuan teknis. Kemampuan-kemampuan tersebut dipercaya dapat memberi kontribusi dan pengaruh positif terhadap keberhasilan pembelajaran. Artinya, bahwa kompetensi pendidik berhubungan erat dengan keberhasilan pembelajaran. Yamin dan Maisah (2010:28) mengatakan, "berkompeten adalah mengedepankan mutu dan kualitas layanan dan produknya, layanan harus memenuhi standarisasi kebutuhan masyarakat, bangsa dan pengguna serta memaksimalkan kemampuan peserta didik berdasar potensi dan kecakapan yang dimiliki masing-masing individu."

Upaya untuk meningkatkan kompetensi dapat dilakukan dengan belajar sendiri (otodidak), mengikuti pelatihan dan studi lanjut pada pendidikan formal ataupun non formal. Hasil penelitian yang menunjukkan bahwa kompetensi berpengaruh terhadap keberhasilan pembelajaran. Artinya, guru yang berkompeten akan lebih memungkinkan untuk berkreasi karena memiliki segudang kemampuan pedagogik, profesional, kepribadian dan sosial. Banyak upaya yang dapat dilakukan untuk 
meningkatkan kompetensi tersebut. Namun untuk hal ini, guru perlu memiliki motivasi, yaitu dorongan untuk mencapainya.

Motivasi adalah bagian penting dalam dalam mencapai sesuatu yang diinginkan. Karena itu, pendidik akan bersemangat melakukan pekerjaan yang digelutinya apabila termotivasi. Guru sebagai tenaga pendidik, pengajar dan pelatih dalam kinerjanya didorong oleh banyak motivasi. Salah satu dari motivasi tersebut adalah tercapainya keberhasilan pembelajaran. Seorang guru dala kinerjanya harus memiliki motivasi yang jelas. Karena itu, seorang pendidik harus memiliki derajat kesediaan dan tingkat kemampuan yang baik. Selain itu, guru harus tetap menjaga kemurnian motivasinya. Memiliki motivasi semangat berkompeten guna mencapai keberhasilan tgasnya. Semangat tersebut mencakup need for achievement, need for affiliation dan need for power.

Berdasarkan pengamatan selama penelitian, terdapat beberapa faktor yang mempengaruhi motivasi, yaitu (1) kesediaan bekerja, meliputi gaji yang cukup, tempat bekerja yang layak, kebutuhan perawatan kesehatan, nama baik dalam pandangan orang lain, rasa diterima dan tergabung dalam suatu kelompok. (2) Keadaan fisik guru terutama pada tingkat kesehatan, tingkat gizi sehari hari yang dimakan, sedangkan tingkat kesehatan tergantung pada usaha pemeliharaan kesehatan fisik para guru. (3) Kompetensi juga dipengaruhi pendidikan, latihan, pengetahuan dan pengalaman guru. (4) Keadaan sekolah. Misalnya: pembagian kerja yang tidak tepat, hubungan kerja yang tidak baik, pimpinan yang sering tidak ditempat, pengolahan material yang tidak baik. (5) Kondisi tempat kerja.

Pada prinsipnya, kompetensi akan menginspirasi para pendidik menciptakan siasat dalam pembelajaran. Kompetensi menjadi suatu perubah energi dan mendorong guru berreaksi efektif dalam pembelajaran. Kompetensi akan memotivasi para pendidik dalam mengajar. Sesuai dengan asal kata "motivasi", yaitu: "motif" yang berarti menjadi sesuatu pemberi dorongan atau tenaga (daya) untuk melakukan sesuatu. 
Kompetensi yang dimiliki guru akan membuatnya percaya diri dalam mendidik dan membuat dirinya semakin krestif dan inovatif. Inovasiinovasi yang dilakukan akan dapat menarik minat peserta didik dalam belajar. Guru mesti mempunyai keyakinan dan harapan bahwa dengan motivasi yang tinggi bersama dengan kompetensi yang baik akan membawa mereka pada keberhasilan pembelajaran.

Kemampuan atau kompetensi pendidik adalah penampilan spesifik yang rasional sebagai harmoni dan pemilihan pengetahuan, keterampilan, dan kemampuan yang dibutuhkan untuk mencapai tujuan. Kompetensi pendidik merupakan bagian penting dalam menunaikan tugas kependidikan sehingga menghasilkan produktivitas yang tinggi. Sebab tanpa kompetensi maka seorang pendidik akan mengalami kesulitan dalam melakukan dan merampungkan tanggung jawwabnya. Pemerintah telah menetapkan kompetensi pendidik dalam UUGD yang terdiri dari kompetensi pedagogik, profesional, sosial dan kepribadian.

Seorang pendidik harus memiliki (a) pengetahuan belajar dan tingkah laku manusia, (b) penguasaan pada bidang ilmu yang dibidanginya, (c) sikap yang tepat tentang dirinya sendiri dan teman sejawat serta bidang ilmunya, (d) keterampilan mengajar. Seorang pendidik mestilah seorang pembelajar, mempelajari berbagai ilmu yang berkaitan dengan kepakaran yang dimilikinya. Selain itu, pendidik harus memiliki kemampuan menggunakan metode dan media pendidikan. Untuk menjaga mutu seorang pendidik dan meningkatkan kompetensi, maka pendidik harus selalu menjadi individu yang selalu ingin terus belajar dalam upaya meningkatkan diri. Sebab pendidikan formal yang sudah dimiliki bukanlah akhir dari persiapan menjadi pendidik. Drost dalam Paul Suparno (2002:106) menyarankan apa yang dinamakan dengan on-going formation. Pendidik membutuhkan dan mencari tempat serta sarana untuk mengembangkan diri.

Japarlin Marbun (2011:331) mengatakan, menghadapi tantangan era global, dibutuhkan pendidik berkompeten. Pendidik yang mengabdikan diri sepenuhnya untuk melaksanakan tuntutan profesinya, bukan dengan terpaksa sehingga 
melaksanakan tugas mengajarnya dengan setengah hati. Samuel Sidjabat (1994:120-121) menuliskan bahwa, "kemampuan pendidik bergantung pada kemampuannya, itulah sebabnya penting artinya dari pendaftaran dan pelatihan caloncalon pendidik atau pemimpin dengan persyaratan yang ditentukan.” Selanjutnya Marbun (2011:332) dalam bukunya The Unfinished Task mengemukakan tiga tugas profesi pendidik, yaitu: mendidik, mengajar dan melatih. Mendidik berarti meneruskan dan mengembangkan nilai-nilai hidup, (2) mengajar berarti meneruskan dan mengembangkan ilmu pengetahuan, (3) melatih berarti mengembangkan keterampilanketerampilan pada siswa.

Melaksanakan tugas dan tanggung jawab mendidik, mengisyaratkan bahwa pendidik dituntut memiliki sejumlah kemampuan dan keterampilan tertentu. Artinya, pendidik harus menguasai dan memiliki sejumlah kompetensi dalam teknik dan strategi mendidik. Sama pentingnya dalam hal tugas mengajar, seorang pendidik mesti menguasai berbagai metode mengajar dan mampu menerapkannya sehingga pembelajaran dapat berjalan efektif dan efisien. Metode dalam mengajar sangat beragam, tetapi tidak ada satu metode yang dapat dan cocok dipakai dalam segala bidang dan waktu. Pendidik harus memiliki kemampuan dalam memilih, mengolah dan menggunakannya.

Selain mendidik dan mengajar, pendidik juga adalah seorang pelatih. Sebagai pelatih, maka harus memiliki sejumlah keterampilan melatih. Ia harus memiliki sejumlah "jurus" dan terampil menggunakannya. Tanpa keterampilan, maka ia akan menghadapi kesulitan dalam melatih. Karena itu, kemampuan dan keterampilan menjadi bagian dari kompetensi seorang pendidik. Tanpa kompetensi tersebut, maka pendidik akan kurang produktif. Hal ini sesuai dengan temuan penelitian yang menegaskan bahwa kompetensi pendidik berpengaruh signifikan terhadap keberhasilan pembelajaran.

Guru harus berupaya meningkatkan kompetensinya sebab berkaitan dengan pengembangan kreativitasnya sebagai pendidik. Dedy Mulyadi (2003) dalam Ridwan mengemukakan bahwa, 
pengembangan diri dapat dilakukan melalui berbagai program dan kegiatan serta berbagai bentuk seperti lokakarya, bedah buku, seminar, diklat, diskusi terbatas (Ridwan, 2009:237). Kreativitas guru dalam pencapaian dharma yang meliputi pendidikan dan pengajaran, penelitian serta pengabdian kepada masyarakat. Banyak upaya yang dapat dilakukan, seperti: (a) Meningkatkan kemampuan dalam membangkitkan semangat belajar peserta didik. (b) Meningkatkan penguasaan dalam metode pembelajaran. (c) Mendisiplinkan diri dalam waktu yang disediakan pada saat melakukan tugas mengajar. (d) Meningkatkan kemampuan dalam mengevaluasi hasil belajar peserta didik. (e) Meningkatkan kemampuannya dalam mengembangkan bahan ajar dari hasil penelitian.

Selain itu, seorang guru perlu (a) meningkatkan kemampuan dalam membuat proposal penelitian, penguasaan terhadap metodologi penelitian dan meningkatkan kepampuan dalam membuat laporan penelitian. (b) Mempublikasikan hasil penelitiannya dalam berbagai jurnal atau media massa. (c)
Meningkatkan frekuensi penelitian dan sebisa mungkin melibatkan peserta didik dalam penelitiannya. (d) Meningkatkan frekuensi keterlibatan dalam pengabdian masyarakat serta mempublikasikan hasil pengabdian tersebut.

Kompetensi guru sangat berpengaruh terhadap keberhasilan pembelajaran sesuai dengan hasil penelitian. Karena itu, guru harus secara konsisten meningkatkan kompetensinya sebagai pendidik. Sekolah harus mengupayakan peningkatan kompetensi guru supaya mereka dapat merasa nyaman, termotivasi dan merasakan kepuasan dalam melakukan tugasnya sebagai pendidik. Seorang guru wajib meningkatkan kompetensinya sehingga dapat mendidik secara dinamis dan inovatif guna membatu dalam mencapai keberhasilan pembelajaran.

\section{Simpulan}

Dari hasil pengolahan data yang telah dilakukan, maka dihasilkan temuan penelitian terhadap hipotesis yang berbunyi: kompetensi guru berpengaruh signifikan terhadap keberhasilan pembelajaran dapat 
diterima kebenarannya. Hasil analisis memperlihatkan nilai konstantanya sebesar 65,518. Menyatakan bahwa jika tidak ada kenaikan nilai dari variabel $(\mathrm{X})$, maka nilai $(\mathrm{Y})$ tetap sebesar 65,518. Koefisien regresinya adalah 0,516 menyatakan bahwa setiap penambahan nilai maka $X$ memberikan kenaikan skor 0,516.

\section{Coefficients Variabel YX} memperlihatkan nilai probabilitas sig $=0,020$ lebih kecil dari 0,05 atau nilai $0,05>0,020$, artinya koefisien regresi adalah signifikan. Besar nilai koefisien determinasi adalah 22,6\% variabel $\mathrm{Y}$ dapat dijelaskan oleh variabel X. Kemudian $77,4 \%$ variabilitas $\mathrm{Y}$ diterangkan oleh variabel lain. Simpulannya adalah kompetensi guru berpengaruh signifikan terhadap keberhasilan pembelajaran.

Kesimpulan tersebut memberi beberapa implikasi yang relevan, yaitu: Pertama, guru harus meningkatkan kompetensi pedagogik, kepribadian, profesional dan sosial. Kedua, guru harus konsisten dan berkelanjutan memikirkan dan mengupayakan strategi peningkatan keberhasilan pembelajaran. Upaya yang dapat dilakukan adalah (1) merencanakan dan mempersiapkan pembelajaran dengan baik, (2) meningkatkan motivasi dan semangat peserta didik, (3) meningkatkan kemampuan dalam penggunaan media dan teknologi pembelajaran serta memperhatikan hasil belajar peserta didik dengan baik, (4) proses dan suasana kegiatan belajar mengajar, perubahan tingkah laku dan ketahanan hasil belajar serta perilaku akibat proses pembelajaran.

Sebagai bagian akhir dari penelitian ini, maka: Pertama, para guru wajib meningkatkan kompetensinya baik melalui belajar sendiri, studi lanjut di lembaga pengelola atau lembaga penyelia yang lain agar lebih berkompeten. Kedua, yayasan dan pengelola sekolah dalam melaksanakan rekrutmen guru lebih memperhatikan aspek kompetensi sesuai dengan tuntutan UUGD 14/2005. Ketiga, pengelola sekolah perlu mengupayakan langkah-langkah dalam meningkatkan kompetensi guru.

\section{DAFTAR PUSTAKA}

A. M, Sardiman. 1990. Interaksi dan 
DIEGESIS: Jurnal Teologi

Volume 6 No. 1, Februari 2021 Hlm 49-69

Motivasi Belajar Mengajar, Jakarta: Rajawali Press.

Harefa, Andrias. 2000. Menjadi Manusia Pembelajar, Jakarta: Harian Kompas.

Husdarta, H.J.S. 2009. Manajemen Pendidikan Jasmani, Bandung: Alfabeta.

Jihad, Asep dan Haris, Abdul. 2008. Evaluasi Pembelajaran, Yogyakarta: Multi Pressindo

Marbun, Japarlin. 2011. The Unfinished Task: Tugas Yang Belum Selesai, Jakarta: GBI Permata.

Mulyasa, E. 2011. Menjadi Dosen Profesional Menciptakan Pembelajaran Kreatif dan Menyenangkan, Bandung: Rosdakarya.

Ridwan dan Kuncoro, Achmad Engkos. 2007. Cara Menggunakan dan Memaknai Analisis Jalur (Path Analysis), Bandung: Alfabeta.

Sanjaya, Wina. 2006. Strategi Pembelajaran Berorientasi Standar Proses Pendidikan, Jakarta: Prenada Media Group.

Slameto. 1995. Belajar dan FaktorFaktor yang Mempengaruhinya, Jakarta: Rineka Cipta.

Sudjana, Nana. 1988. Dasar-dasar Proses Belajar Mengajar, Bandung: Algesindo.

Sumardjoko, Bambang. 2010. Membangun Pendidikan Mutu Perguruan Tinggi Analisis
Perguruan Tinggi Swasta di Surakarta, Yogyakarta: Pustaka Pelajar.

Yamin, Martinis dan Maisah. 2010. Standarisasi Kenerja Guru, Jakarta: Gaung Persada Press. 